\title{
Study on Agarwood and caspase-3 activation in rat liver toxicity induced by methanol
}

\begin{abstract}
Agar wood has been applied to traditional medicine and used as perfumery and food ingredients especially in Saudi Arabia. It contains bio molecules component that shows various pharmacological, anti-mutagenic, anti-tumor and anti-helminthic, antioxidant and other advantages effects. Reactive oxygen species (ROS) produced during the detoxification of xenobiotics and drugs that generated oxidative stress and apoptosis. Caspase- 3 is the central executioners, a cysteine protease, during apoptosis and cell death. The effect of Agar wood hexane extract on liver death through studied of nitric oxide (NO), malondialdehyde (MDA), caspase-3 levels and liver function tests in rats treat and untreated with an intra peritoneal dose of $3 \mathrm{~g} / \mathrm{kg}$ methanol was studied in this investigation. Injected of rats with methanol-induced an elevation in the levels of $\mathrm{NO}$, MDA, caspase-3, and liver function tests, compared to the control. Treatment of animals with Agar wood extracts pre, during, and post methanol administration improved liver function and decreased the levels of NO, MDA, and caspase-3 activities compared to the methanol group, indicates that Agar wood diminished the oxidative stress and apoptosis induced by methanol, this may be due to its Phytochemical compositions.
\end{abstract}

Keywords: agarwood, apoptosis, caspase-3, oxidative stress, methanol, liver, rat
Volume 6 Issue 2 - 2018

\author{
Asmaa F Hamouda, ', ' Nadia Z Shaban,' \\ El-Kersh Mohamed AR,' Azzah F AL Thaali, ${ }^{3}$ \\ Ibrahim A Khardalic, ${ }^{4}$ Magbool E Oraiby, ${ }^{4}$ M \\ Ahmad Atafi ${ }^{4}$ \\ 'Department of biochemistry, Faculty of Science, University of \\ Alexandria Egypt \\ ${ }^{2}$ Medical Laboratory Technology Department, Faculty of Applied \\ Health Sciences, Jazan University, Saudi Arabia \\ ${ }^{3}$ Department of chemistry, University of AI Leith-Umm AI-Qura, \\ Saudi Arabia \\ ${ }^{4}$ Poison Control and Medical Forensic Chemistry Center, \\ Ministry of Health, Kingdom of Saudi Arabia
}

Correspondence: Asmaa Fathi Hamouda, Assistant Professor in Faculty of Applied Health Sciences, Jazan University, Saudi Arabia,Email asmaakingdom I@yahoo.com

Received: March 20, 2018 | Published: April 13, 2018
Abbreviations: NO, nitric oxide; MDA, malondialdehyde; ROS, reactive oxygen species; AW, Agarwood; ALT, Alanine aminotransferase; AST, Aspartate Aminotransferase

\section{Introduction}

Agarwood (Aquilariasinensis, Aquilariacrasna) is widely recognized as incense in Thailand, Cambodia, and Taiwan. The Agarwood leaves also being treated as health tea product in some countries such as Taiwan and Thailand. The term "Agarwood" refers to resin-impregnated pieces of wood that have been at least slightly stripped from the non-impregnated woods. ${ }^{1-2}$ Agarwood is applied for fragrance, perfume, traditional medicine, and other products in the world market. In traditional Chinese medicine, agar wood is used as a qi-regulating drug and carminative medicine to dismiss gastric obstacles, coughs, rheumatism, and high fever. It can promote qi circulation to relieve pain and anxiety, warm the middle energizer to arrest vomiting and regulate respiration to alleviate asthma. ${ }^{3}$ In traditional Arabian medicine, agar wood essential oil is used for aromatherapy. Concurrently, agar wood has also been widely used for centuries as incense in Buddhist, Hindu, and Islamic traditions. ${ }^{1-3}$ The target of this study indicates the effect of Agarwood on liver injuries induced with methanol. Methanol is produced endogenously, as a consequence of mediator metabolism. It is also already in the diet, distinctly in storage fruit and vegetables and their juices and synthetically made beverages, drinks, and the perfumes. Methanol toxicity may initially appear in CNS depression, followed by a possible asymptomatic period metabolic acidosis and ocular toxicity that may end in blindness, are resulting manifestations of digestive problems toxicity, coma, and death.,5. Natural food and herbs are conventional to treat toxicity, chronic and acute illness. No adequate scientific data on agar wood in Saudi Arabia, however, both methanol and Agarwood enter into perfumes composition that used daily in Saudi Arabia. ${ }^{5-8}$ So, this studies to investigate the effect of Agarwood on the healthy liver and handling methanol effects. Also, study the chemoprevention of Agarwood (AW) against liver Methanol toxicity. Through following the changes in nitric oxide (NO), malondialdehyde (MDA), caspase-3, and liver function levels in liver in rats treat, and untreated with Methanol.

\section{Experimental procedures}

\section{Chemicals}

Sulphanilamide, Standard sodium nitrite, N-1-Naphthyl ethylene diamine, and sodium dodecyl sulfate (SDS), thiobarbituric acid (TBA), tetramethoxypropan (TMP) and Diethylene triaminopentaacetic, purchased from Sigma-Aldrich, USA, (DTPA). A caspase-3 assay kit purchased from BioSource International, Inc. (Camarillo, CA, USA).

\section{A selection of the plant materials and extraction of cured extract}

Agarwood chips [Cambodia Agar wood] accumulated from a local market in Saudi Arabia. Agarwood chips crushed and extracted with hexane. Following Covered in a solvent for two days at room temperature $\left(28 \pm 2^{\circ} \mathrm{C}\right)$, the extract reduced applying a rotary evaporator at $40-50^{\circ} \mathrm{C}$. The plant $(500 \mathrm{~g})$ extracted with hexane yield $(12 \mathrm{~g}) .{ }^{9,10}$

\section{Animals}

40 adult male Sprague-Dawley rats weighing 100-110g applied in this research. All rats were tested for health status at $25^{\circ} \mathrm{C}$, given standard diet and water daily for two weeks before approach. After acclimatization, rats were distributed into four groups of 10 rats. All animal investigations established by the Ethics Committee of the Experimental Animal Care Society and according to the Three Rs (3Rs: Replacement, Reduction, Refinement) in scientific testing research. ${ }^{11}$ 
a. The control group $(\mathrm{C})$ : non-treated rats.

b. (Methanol) group: The rats were infused with the intraperitoneal dose of $3 \mathrm{~g} \mathrm{~kg}^{-1}$ body mass (b.m) methanol one per week for three weeks. ${ }^{12-14}$ The test period is 35 days.

c. (AW) group: the rats treated orally with a daily dose of AW (Agarwood) $100 \mathrm{mg} \mathrm{kg}^{-1}$ body mass (bm) for 35 days. ${ }^{8,11}$ The test period is 35 days.

d. (AW- Methanol) group: Examined rats orally with a daily dose of AW $100 \mathrm{mg} \mathrm{kg}^{-1}$ body mass (bm) for a week. The animals managed with Methanol (as described before) at the beginning of the second week in addition to a daily dose of AW until whole 35 days. ${ }^{8,14}$ The trial period is 35 days. Subsequent the trial time, before rats anesthetized with diethyl ether and sacrificing, feeding stopped for 12 hours. The liver tissues washed with a cold saline solution $(0.9 \% \mathrm{NaCl})$, weighed, and stored at $-80^{\circ} \mathrm{C}$ until used for biochemical interpretation.

\section{Biochemical assay}

NO level: It was determined spectrophotometrically ${ }^{15}$ the Liver tissues separately homogenized in four volumes of cell lysate buffer ( $\mathrm{pH}$ 7.5). The homogenate of liver separately centrifuged at $10,000 \mathrm{~g}$ for one min at $4 \mathrm{C}^{\circ}$ and the supernatant saved at $-30 \mathrm{C}^{\circ}$ until handled. $100 \mu \mathrm{l}$ of sample (liver or standard sodium nitrite $100 \mu \mathrm{M}$ ) combined with $1 \mathrm{ml}$ of Sulphanilamide. $50 \mu \mathrm{N}$-1-Naphthyl ethylene diamine added, and then incubated at room Temperature for $20 \mathrm{~min}$. Following that the absorbance recorded at $540 \mathrm{~nm}$ against a blank (since the buffer was scored alternatively of the sample).

Lipid peroxidation: We applied the calorimetric method for MDA level, the end product of lipid peroxidation, measurement. ${ }^{16}$ Fifty micro liters of the Liver tissues separately homogenate or the buffer that applied in homogenization process (blank) incubated with examine mixture that included $(100 \mu \mathrm{L}$ of $8.1 \%$ of SDS, $750 \mu \mathrm{L}$ of $20 \%$ acetic acid including $\mathrm{HCl}, 750 \mu \mathrm{L}$ of $0.8 \%$ TBA, and $300 \mu \mathrm{L}$ of distilled water) $\mathrm{pH} 3.5$. Then the mixture placed in boiling water bath for $45 \mathrm{~min}$. At room temperature, after cooling, add $500 \mu \mathrm{L}$ of distilled water and $2.5 \mathrm{~mL}$ of $\mathrm{n}$-butanol/pyridine mixture $(15: 1 \mathrm{v} / \mathrm{v})$, stirred well, and centrifuged for $10 \mathrm{~min}$ at $1780 \mathrm{~g}$. Then we estimated the absorbance of the pink color at $532 \mathrm{~nm}$ and fixed the concentration of MDA as nmol/g liver. Then we applied different concentrations of TMP (20-300 nmol) as standard and assay in a related way as the sample.

Caspase-3 assay: Caspase- 3 activity examined using a colorimetric kit according to the method of ${ }^{17}$ Liver tissues separately homogenized in four volumes of cold cell lysis buffer $(50 \mathrm{mM}$ Tris-HCl buffer Table I Different biochemical analysis including $0.2 \mathrm{M} \mathrm{NaCl}$ and $1 \%$ Triton $\mathrm{X}-100, \mathrm{pH} 6.8$ ) by a Teflonglass homogenizer. The homogenates were centrifuged at 44,720 g for $3 \mathrm{~min}$ at $4{ }^{\circ} \mathrm{C}$, and the supernatants kept at $-80^{\circ} \mathrm{C}$. The supernatant $(50 \mu \mathrm{L}=150 \mu \mathrm{g}$ protein $)$ put in a micro plate reader, and then 50 micro liters $(\mu \mathrm{L})$ reaction buffer and five micro liters $(\mu \mathrm{L})$ of 4 mill molar $(\mathrm{mM})$ substrate were combined, stirred well, and incubated at $37^{\circ} \mathrm{C}$ in the darkness for 2 hours. The reaction rate concluded by measuring the absorbance of the produced yellow color at 405 nanometers $(\mathrm{nm})$ against a blank handling a micro plate reader (Bio-Tek Instruments, Bad Friedrichshall, Germany). Fold increase in caspase-3 activity should conclude by direct comparison to the level of the control.

Liver function: AST and ALT activities assay and Total bilirubin concentration determined according to the processes of and Frankel et al. ${ }^{18}$ and Jendrassik ${ }^{19}$ sequentially.

Statistical analysis: Statistical analysis: All data show as means (X) \pm standard deviation (S.D). Comparisons between the means of various treatment groups were analyzed using least significant difference (LSD) test. Variations were judged significant at $\mathrm{p}<0.05$. All statistical examinations were done using the statistical software SPSS v11.5 (SPSS, Inc., Chicago, IL, USA).

\section{Results \\ NO level}

NO results in liver tissue reported the NO level in C were $24.71 \pm 0.13 \mu \mathrm{m}$ lower than that in Methanol group $87.09 \pm 1.01 \mu \mathrm{m} ; \mathrm{p}<$ 0.05. Liver, NO levels in AW group, was $24.69 \pm 1.02 \mu \mathrm{m}$ compared to $C ; \mathrm{p}<0.05$. Liver NO levels in AW-Methanol was $48.71 \pm 0.03 \mu \mathrm{m}$ compared to Methanol; $\mathrm{p}<0.05$ (Table 1).

\section{Lipid peroxidation (MDA)}

The MDA results in liver tissue showed the MDA level in $\mathrm{C}$ were $1.65 \pm 1.00 \mathrm{nmol} / \mathrm{g}$ tissue lower than that in Methanol group $17.44^{\mathrm{b}} \pm 1.02 \mathrm{nmol} / \mathrm{g}$ tissue; $\mathrm{p}<0.05$. While Liver MDA levels in AW group were $1.65 \pm 0.04 \mathrm{nmol} / \mathrm{g}$ tissue compared to $\mathrm{C}$; $\mathrm{p}<0.05$. in the other hand liver MDA levels in AW-Methanol were $3.01 \pm 0.13 \mathrm{nmol} / \mathrm{g}$ tissue compared to Methanol; $\mathrm{p}<0.05$. (Table 1)

\section{Caspase-3}

The result of Caspase- 3 levels in liver tissue showed the Caspase- 3 level in $\mathrm{C}$ were $0.17 \pm 0.02$ lower than that in Methanol group, $0.81 \pm$ $0.02 ; \mathrm{p}<0.05$. Liver Caspase -3 levels in AW group were $0.17 \pm 0.03$ compared to $\mathrm{C} ; \mathrm{p}<0.05$. Liver Caspase-3 levels in AW-Methanol was $0.43 \pm 0.01$ compared to Methanol; $\mathrm{p}<0.05$. (Table 1)

\begin{tabular}{lllll}
\hline Particulars & C & Methanol & $\begin{array}{l}\text { AW- } \\
\text { Methanol }\end{array}$ & AW \\
\hline Serum & & & & \\
ALT (U/L) & $0.65^{\mathrm{a}} \pm 0.01$ & $82.05^{\mathrm{b}} \pm 0.03$ & $2.91^{\mathrm{c}} \pm 0.04$ & $0.65^{\mathrm{a}} \pm 0.10$ \\
AST (U/L) & $11.01^{\mathrm{a}} \pm 0.02$ & $21.2^{\mathrm{b}} \pm 1.00$ & $11.02^{\mathrm{a}} \pm 1.02$ & $11.00^{\mathrm{a}} \pm 0.01$ \\
Bilirubin (mg/dl) & $0.68^{\mathrm{a}} \pm 0.42$ & $1.87^{\mathrm{b}} \pm 0.02$ & $0.78^{\mathrm{c}} \pm 0.17$ & $0.68^{\mathrm{a}} \pm 0.01$ \\
Tissue & & & & \\
Caspase-3 & $0.17^{\mathrm{a}} \pm 0.02$ & $0.81^{\mathrm{b}} \pm 0.02$ & $0.43^{\mathrm{c}} \pm 0.01$ & $0.17^{\mathrm{a} \pm 0.03}$ \\
Malondialdehyde (MDA) levels (nmol/g tissue & $1.65^{\mathrm{a}} \pm 1.00$ & $17.44^{\mathrm{b}} \pm 1.02$ & $33.01^{\mathrm{c}} \pm 0.13$ & $1.65^{\mathrm{a}} \pm 0.04$ \\
NO concentration $(\boldsymbol{\mu m})$ in LIVER tissues & $24.7 I^{\mathrm{a}} \pm 0.13$ & $87.09^{\mathrm{b}} \pm 1.01$ & $48.7 I^{\mathrm{c}} \pm 0.03$ & $24.69^{\mathrm{a}} \pm 1.02$ \\
\hline
\end{tabular}




\section{Liver function}

ALT,AST and bilirubin levels were $(0.65 \pm 0.01 \mathrm{U} / \mathrm{L}, 11.01 \pm 0.02 \mathrm{U} / \mathrm{L}$, $0.68 \pm 0.42 \mathrm{mg} / \mathrm{dl})$ in C lower than that in Methanol group $(82.05 \pm 0.03$ $\mathrm{U} / \mathrm{L}, 21.2 \pm 1.00 \mathrm{U} / \mathrm{L}, 1.87) \pm 0.02 \mathrm{mg} / \mathrm{dl}$ ) respectively; $\mathrm{p}<0.05$ (Table 1). ALT, AST and bilirubin levels in AW-Methanol were $(2.91 \pm 0.04$ $\mathrm{U} / \mathrm{L}, 11.02 \pm 1.02 \mathrm{U} / \mathrm{L}, 0.78 \pm 0.17) \mathrm{mg} / \mathrm{dl}$ compared to Methanol group $\mathrm{p}<0.05$. ALT, AST and bilirubin levels in AW were $(0.65 \pm 0.10 \mathrm{U} / \mathrm{L}$, $11.00 \pm 0.01 \mathrm{U} / \mathrm{L}, 0.68 \pm 0.01 \mathrm{mg} / \mathrm{dl}$ ) compared to control group $\mathrm{p}<0.05$. (Table 1)

\section{Discussion}

The liver is the central part of metabolism for methanol where methanol is oxidized to formaldehyde (HCHO), methanoic acid $(\mathrm{H} \cdot \mathrm{COOH}$, formic acid $)$ and eventually detoxified to carbon dioxide $\left(\mathrm{CO}_{2}\right) 1$. In humans and primates, the toxicity of methanol mediated by metabolites and not the original molecule. Formic acid is tested to be the critical toxicant in the animal with a reduced capacity to metabolize this lethal output toxicity may happen from an excellent anion passage metabolic acidosis and neuronal toxicity. ${ }^{4}$ Experimental research demonstrates that there are many adverse health effects of consequences of food alcohols included liver cirrhosis, the mental illness, and numerous kinds of cancer and other. Human exposure to $\mathrm{CH}_{3} \mathrm{OH}$ necessarily happens via the ingestion of alcoholic beverages and fruit juices, use of cosmetics, deicing fluids, varnishes, and perfumes. Because $\mathrm{CH}_{3} \mathrm{OH}$ found relatively ubiquitously in our environment, it frequently fits necessary to know its toxic effects and method of protection and treatment, ${ }^{19-22}$ so we mimic this action by induction of liver injuries by methanol administration in present experimental study. The present result revealed that increase nitric oxide (NO), malondialdehyde (MDA), caspase-3 and liver function test levels in liver in rats treat with methanol as compared with control. The results showed the methanol itself or its metabolitecaused oxidative stress that characterized by an imbalance between pro-oxidant and antioxidant in the direction of the pro-oxidants that led to tissue damages, inflammation, and apoptosis in liver tissues.

The interaction between alcohol metabolism byproducts and other cell parts led to the production of toxic compounds (i.e., adducts); formation of highly reactive oxygen-containing molecules (i.e., reactive oxygen species $[\mathrm{ROS}]$ ) that combat cell membrane, protein, lipid and DNA and led to injuries and cell death. The hepatocytes must take up more oxygen than usual from the blood to have enough oxygen available to accept the electrons and indeed led to hypoxia. According to scientific reports, Methanol poisoning has become a considerable health obstacle. The liver can show some features of poisoning after methanol ingestion and histological changes in liver tissues was observed. ${ }^{22}$ Methanol itself or its metabolites led to Liver injuries through an effect on pro-oxidant and free radicals stability. Nitric oxide (NO) represents a vital role in neurotransmission, vascular management, immune response, and apoptosis. MDA is a primary oxidation output of peroxidized polyunsaturated fatty acids and improved MDA content is an essential indicator of lipid peroxidation that agrees with a present result. The current research has shown a significant elevation in MDA, NO, caspase-3, and liver function levels after Methanol treatment as a result of the formation of lipid peroxides in liver crude homogenates response to the administration of methanol. The issues may be due to some enhanced generation free radicals that stimulated peroxidation of natural membrane lipids. Peroxidation of the mitochondrial membrane led to a lack of cell integrity, rise in membrane permeability, and alteration of $\mathrm{Ca}^{2+}$ homeostasis that contribute cell death due to change in the inner membrane potential as well as led to release of liver enzyme and destruction of the liver cells..$^{23-27}$

Agarwood used in Saudi Arabia in the extensive area and across the Middle East. While Agarwood is popularly used in perfumes and incense in daily applications that force us to study the biological effect of Agarwood-consuming. The present results confirmed that a significant decline in liver NO, MDA, Caspase-3 and liver function in AW-Methanol compared to the Methanol. While there is no substantial change in the levels of NO, MDA, Caspase-3 and liver function in rat treat with Agarwood alone in the liver as compared to a control group that indicated that Agarwood extract oil has selective roles in their consequences. Oxidative stress is a part of several diseased maladies including inflammation. Scientists published that inhibition and repression antioxidant Phytochemistry reduced inflammation and apoptosis in rats that agree with our results in AW-Methanol. The present work meant that Agarwood reduces apoptosis that evident in inhibition of caspase-3 in liver tissue which induces with methanol that coincides with other reported. The report indicated that $\beta$-caryophyllene, essential Agarwood oil, can suppress metastasis of colon cancer and have the anti-inflammatory and antioxidant property that makes Agarwood able to management inflammation-related conditions. Furthermore, Agarwood contains essential bioactive parts such as alkaloids, tannins, flavonoids and phenolic compounds that include agarofuran, guaiol, Selinene that has superior anticancer and antioxidant activity and central nervous system antidepressant actions. $^{28-30}$ The other investigation confirmed that Agarwood components had been shown to possess anti-inflammatory, antinociceptive, neuroprotective, and anticonvulsant characteristics. ${ }^{29,30}$ The present results suggested that Agarwood composition can act liver beneficial effect that may have the encouraging agent in the handling of liver health against the toxic compound.

\section{Conclusion}

The restraint of NO, MDA, Caspase-3, and liver function level of liver tissue that restored to near control levels before, during and post Methanol could make Agarwood healthy dietary state for the blocking/authority of liver diseases.

\section{Acknowledgment}

The authors appreciate Taymour-Lank M. Farawilla

\section{Conflict of interest}

There are no conflicts to declare.

\section{References}

1. Hashim YZ, Kerr PG, Abbas P, et al. Aquilaria spp. (Agarwood) as Source of Health Beneficial Compound: A Review of Traditional Use, Phytochemistry and Pharmacology. J Ethnopharmacol. 2016;189:331360 .

2. Azah N, Chan YS, Mailina J, et al. Comparison of chemical profiles of selected gaharu oils from Peninsular Malaysia. Malaysian J Anal Sci. 2008;12(2):338-340.

3. Chen HQ, Wei JH, Yang JS, et al. Chemical constituents of agarwood originating from the endemic genus Aquilaria plants. Chem Biodivers. 2012;9(2):236-250. 
4. Fein DM, Sue YJ. Methanol ingestion. Pediatr Rev. 2011;32(12):549-550.

5. Huaiqiong C, Yun Y, Jian Xue, et al. Comparison of Compositions and Antimicrobial Activities of Essential Oils from Chemically Stimulated Agarwood, Wild Agarwood and Healthy Aquilaria sinensis (Lour.) Gilg Trees. Molecules. 2011;16(6):4884-4896.

6. Kakino M, Tazawa S, Maruyama H, et al. Laxative effects of agarwood on low-fiber diet-induced constipation in rats. BMC Complement Altern Med. 2010;10:68.

7. Hitoshi O, Reiko U, Katsuhiko M, et al. Effects of Agarwood Extracts on the Central Nervous System in Mice. Planta Med. 1993;59(1):32-36.

8. Mamoru K, Shigemi T, Hiroe M, et al. Laxative effects of agarwood on low-fiber diet-induced constipation in rats. BMC Complement Altern Med. 2010;10:68.

9. Yang-yang L, Jian-he W, Zhi-hui G, et al. A Review of Quality Assessment and Grading for Agarwood. Chinese Herbal Medicines. 2017;9(1):22-30.

10. Lee YN, Yunus ACM, Idham Z, et al. Extraction and identification of bioactive compounds from agarwood leaves. IOP Conf Ser: Mater Sci Eng. 2017;162(1):012028.

11. Hamouda AF. Ethical to using Rats in the Scientific Researches. Pharm Pharmacol Int J. 2018;6(1):22-24.

12. Kurcer MA, Kurcer Z, Koksa M, et al. Effect of lycopene on caspase-3 enzyme activation in liver of methanol-intoxicated rats: comparison with fomepizole. J Med Food. 2010;13(4):985-991.

13. Mc Cord CP. Toxicity of methyl alcohol (methanol) following skin absorption and inhalation. Ind Eng Chem. 1931;23(8): 931-936.

14. Gilger AP, Potts AM. Studies on the visual toxicity of methanol, The role of acidosis in experimental methanol poisoning. Am J Ophthalmol. 1955;39(2 Pt 2):63-86.

15. Montgomery H, Dymock J. The Determination of Nitrite in Water. Analyst. 1961;86:414-416.

16. Ohkawa H, Ohishi N, Yagi K. Assay for Lipid Peroxides in Animal Tissues by Thiobarbituric Acid Reaction. Anal Biochem. 1979;95(2):351-358.

17. Talanian RV, Quinlan C, Trautz S, et al. Substrate Specificities of Caspase Family Proteases. J Biol Chem. 1997;272(15):9677-9682.

18. Reitman S, Frankel S. A Colorimetric Method for the Determination of Serum Glutamic Oxalacetic and Glutamic Pyruvic Transaminases. Am J Clin Pathol. 1957;28(1):56-63.
19. Jendrassik L. Simplified photometric methods for the determination of blood bilirubin. Biochem J. 1938;297:82-89.

20. Jason MH, Kristi MC, Craig H. Methanol, Formaldehyde, and Sodium Formate Exposure in Rat and Mouse Conceptuses: A Potential Role of the Visceral Yolk Sac in Embryotoxicity. Birth Defects Res A Clin Mol Teratol. 2005;73(2):72-82.

21. Naik NTK, Suresh B. Impact of Alcohol Consumption on Health and Economy (A Focus on Mc Dowellization of World). IOSR Journal of Nursing and Health Science. 2013;1(5):18-23.

22. Samir Z. Overview: How Is Alcohol Metabolized by the Body? Alcohol Research \& Health. 2006;29(4):245-254.

23. Akhgari M, Panahianpour MH, Bazmi E, et al. Fatal methanol poisoning: features of liver histopathology. Toxicol Ind Health. 2013;29(2):136-141.

24. Nadia ZS, Mohamed ARK, Mohamed MBE, et al. Effect of Punica Granatum (Pomegranate) Juice Extract on Healthy Liver and Hepatotoxicity Induced by Diethylnitrosamine and Phenobarbital in Male Rats. J Med Food. 2014;17(3):339-349.

25. Asmaa FH, Nadia ZS, Iman MT. Effects of Some Pyrimidine Derivatives and Pomegranate Juice on Male Rat Kidney Injuries Induced by Diethylnitrosamine and Carbon tetrachloride. Biol Chem Res. 2015;201:215-229.

26. Hamouda A, Shaban N. Short and long-term effects of pomegranate extracts (Punica granatum) on apoptosis in rat kidney Induced by Diethylnitrosamine and Phenobarbital. Journal of Pharmacy and Pharmacology. 2016;4:52-63.

27. Hamouda FA. Study on the effect of avocado extract on apoptosis, oxidative stress and injuries induced by diethyl nitrosamine in rat liver. Journal of Pharmacy and Pharmacology. 2015;3:243-252.

28. Velier JJ, Ellison JA, Kikly KK, et al. Caspase-8 and Caspase-3 Are Expressed by Different Populations of Cortical Neurons Undergoing Delayed Cell Death after Focal Stroke in the Rat. $J$ Neurosci. 1999;19(14):5932-5941.

29. Khalil AS, Rahim AA, Taha KK, et al. Characterization of Methanolic Extracts of Agarwood Leaves. Journal of Applied and Industrial Sciences. 2013;1(3):78-88.

30. Saad SD, Yasser MT, Mohamed BKA, et al. In vivo anti-inflammatory activity of $\beta$-caryophyllene, evaluated by molecular imaging. Molecules $\&$ Medicinal Chemistry. 2015;1:e1001. 